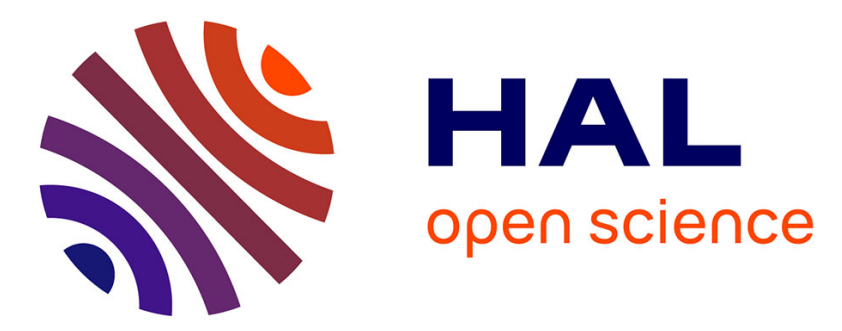

\title{
How Information Systems Assist the Management of the Supply Chain in an Emerging Country Like Brazil
}

\author{
Marcelo T. Okano, Fernando S. Marins, Oduvaldo Vendrametto
}

\section{To cite this version:}

Marcelo T. Okano, Fernando S. Marins, Oduvaldo Vendrametto. How Information Systems Assist the Management of the Supply Chain in an Emerging Country Like Brazil. IFIP International Conference on Advances in Production Management Systems (APMS), Sep 2014, Ajaccio, France. pp.132-141, 10.1007/978-3-662-44739-0_17. hal-01388232

\section{HAL Id: hal-01388232 \\ https://inria.hal.science/hal-01388232}

Submitted on 26 Oct 2016

HAL is a multi-disciplinary open access archive for the deposit and dissemination of scientific research documents, whether they are published or not. The documents may come from teaching and research institutions in France or abroad, or from public or private research centers.
L'archive ouverte pluridisciplinaire HAL, est destinée au dépôt et à la diffusion de documents scientifiques de niveau recherche, publiés ou non, émanant des établissements d'enseignement et de recherche français ou étrangers, des laboratoires publics ou privés.

\section{(c)(1)}

Distributed under a Creative Commons Attribution| 4.0 International License 


\title{
How information systems assist the management of the supply chain in an emerging country like Brazil
}

\author{
Marcelo T. Okano, Fernando A. S. Marins and Oduvaldo Vendrametto
}

\begin{abstract}
.
IT has an important role in the performance of companies, provides a flow of information that makes the supply chain become more robust and resilient, without compromising efficiency. Most companies are applying IT systems, mainly in Supply Chain Management (Supply Chain Management - SCM) to enhance their performance in competitive global markets. The research is important because it will provide a study of what are the IT systems used to manage the supply chain and likely future trends. To achieve the objective of this work was carried out a survey with consultants and professionals in IT and supply chain who work in large companies. To collect the data needed for analysis, we used the exploratory research of a qualitative nature. Thus, we can conclude that the use of IT in the supply chain directly impacts in the areas of planning, manufacturing suppliers, customers and delivery.
\end{abstract}

Keywords: IT, SCM, information systems

\section{Introduction}

Rapid technological change and the need for information are always available to customers and suppliers, practically, is mandatory that all companies involved in any supply chain, use the Information Technology (IT).

Companies seek to adapt to this scenario focusing on performance, seeking to improve the level of service and reduce costs in an attempt to differentiate and increase the perceived value of their customers [1].

IT has an important role in the performance of companies, provides a flow of information that makes the supply chain become more robust and resilient, without compromising efficiency. Most companies are applying IT systems, mainly in Supply Chain Management (Supply Chain Management - SCM) to enhance their performance in competitive global markets [2].

According Prajogo \& Olhager [3] IT can assist the SCM in the following aspects. First, it allows companies to increase the volume and complexity of information that needs to be communicated with its trading partners. Secondly, it allows companies to provide real-time information in the supply chain, including inventory levels, delivery status, and production planning and scheduling which enable companies to manage and control their supply chain activities. Third, it also facilitates the alignment of forecasting and scheduling operations between enterprises and suppliers.

The research is important because it will provide a study of what are the IT systems used to manage the supply chain and likely future trends.

\section{Literature Review}

SCM has always been a challenge for information integration. The idea is to allow everyone involved in the flow of goods can make decisions based on the latest information and better than all others, both upstream and its downstream. The company manages its supply chain better get your product from point of origin to point of consumption in the shortest amount of time with the lowest cost [4].

According to Patterson et al. [5] a variety of factors can affect the decision of an organization to adopt and implement a technology that provides supply chain. The authors classify them into five broad categories: individual, related to task characteristics related to innovation, organizational and environmental. The authors also suggest that these factors may be important to different degrees, depending on the context or technology.

Information systems (IS) are combinations of technologies and people's activities using that technology to support operations, management, and decision-making [6]. 
IS provide many different solutions for almost all areas of business, the SCM uses some. Patterson et al. [5], point 18 IT systems applied to SCM. Table 1 shows the description and associated applications of various software, hardware and management systems.

Table 1 - IT systems applied to SCM

\begin{tabular}{|c|c|}
\hline Technology & Description \\
\hline $\begin{array}{l}\text { Legacy } \\
\text { Systems }\end{array}$ & $\begin{array}{l}\text { Legacy Systems are mainframe-based systems that operate at the operational } \\
\text { level in only one stage. They are constructed as independent blocks, which } \\
\text { hinders their communication with other systems. Systems were first used in } \\
\text { SCM. }\end{array}$ \\
\hline Barcode & $\begin{array}{l}\text { Technology for the allocation of computer readable codes on items, boxes and } \\
\text { containers. Employed to improve the data transmission speed and precision of } \\
\text { the information. It is used in managing inventory, warehouses, supermarkets } \\
\text { and so on. }\end{array}$ \\
\hline CAD & $\begin{array}{l}\text { Allows the realization of industrial designs on the computer screen that can be } \\
\text { stored, manipulated and updated electronically. }\end{array}$ \\
\hline $\mathrm{BI}$ & $\begin{array}{l}\text { Set of applications that organizes and structures the transaction data of an } \\
\text { organization, facilitating the analysis in order to benefit the operations and } \\
\text { decision support. }\end{array}$ \\
\hline EDI & $\begin{array}{l}\text { It is the electronic transfer of data between business partners. The data is } \\
\text { structured according to standards agreed in advance between the parties. } \\
\text { Divided into two categories: traditional EDI, using services of value-added } \\
\text { network, and WebEDI with access forms online (Internet). }\end{array}$ \\
\hline Fleet tracking & $\begin{array}{l}\text { Can be based on satellite transmission or by cell phone for tracking and } \\
\text { monitoring of vehicles, being applied to control performance and safe } \\
\text { transport. The data generated by this system feeding the TMS and WMS. }\end{array}$ \\
\hline AQC & $\begin{array}{l}\text { Responsible for monitoring the processes of quality assurance, inspection, } \\
\text { specifications and calibration of measuring instruments. }\end{array}$ \\
\hline MES & $\begin{array}{l}\text { Planning systems that aim to optimize and synchronize their use. } \\
\text { Supports the exchange of information between production planning and } \\
\text { control of the production process through the monitoring and tracking of raw } \\
\text { materials, equipment, personnel, instruction and production facilities. }\end{array}$ \\
\hline TMS & $\begin{array}{l}\text { Responsible for controlling the transport of loads, determining the modal, } \\
\text { freight consolidation managing and coordinating the efforts of transport. }\end{array}$ \\
\hline WMS & $\begin{array}{l}\text { Optimizes operating activities (material flow) and administrative (information } \\
\text { flow) in the process of storage, tracking and controlling the movement of } \\
\text { inventory in the warehouse. Its use is restricted to operational decisions, such } \\
\text { as: definition of collection routes, addressing products, etc.. }\end{array}$ \\
\hline CRM & $\begin{array}{l}\text { Tool to unify customer information and create a single, centralized interactions } \\
\text { and anticipating customer needs. It also provides control of promotional } \\
\text { activities and their impact on demand as well as the control of activities of } \\
\text { product warranty. }\end{array}$ \\
\hline PDM & $\begin{array}{l}\text { Manages information related to products, serving as an integration tool that } \\
\text { connects different areas of product development. }\end{array}$ \\
\hline $\mathrm{RF}$ & $\begin{array}{l}\text { Facilitates communication, providing essential information on the status of the } \\
\text { products. Support tool that automates and improves the management of } \\
\text { operations, eliminating human error. }\end{array}$ \\
\hline SCP & $\begin{array}{l}\text { Assists in the planning, execution and measurement of processes, including } \\
\text { modules for demand forecasting, inventory planning and distribution. }\end{array}$ \\
\hline DFS & $\begin{array}{l}\text { Uses mathematical methods that manipulate historical data and external data } \\
\text { to forecast demand for products and services. In general, integrated systems, } \\
\text { such as ERP and SCP. }\end{array}$ \\
\hline WIS & $\begin{array}{l}\text { Facilitates internal and external processes of enterprises, integrating } \\
\text { enterprise information systems. In SCM, the WIS more presents are e- } \\
\text { procurement and e-market place, which are systems of process automation }\end{array}$ \\
\hline
\end{tabular}




\begin{tabular}{|l|l|}
\hline & corporate purchases. \\
\hline B2B & $\begin{array}{l}\text { Electronic marketplaces where suppliers and buyers interact to conduct } \\
\text { transactions. It is an e-business, that is, relations between companies. }\end{array}$ \\
\hline ERP & $\begin{array}{l}\text { Unified system that integrates departments and functions of the company. } \\
\text { Improves the flow of information chain in such a degree that it has become a } \\
\text { standard operation. }\end{array}$ \\
\hline
\end{tabular}

Morais and Tavares [7] highlight several benefits provided by IT systems, as shown in table 2:

Table 2 - Benefits of IT systems applied to SCM

\begin{tabular}{|l|l|}
\hline Technology & \\
\hline Barcode & $\begin{array}{l}\text { - Replaces the process of collecting and exchanging information paper, with } \\
\text { risks of error and rework constant. } \\
\text { - Rapid deployment, } \\
\text { - Easy to use } \\
\text { - Compact Equipment }\end{array}$ \\
\hline CAD & $\begin{array}{l}\text { - Creation of movements in the drawing, allowing testing before production. } \\
\text { - Reduced time for product development } \\
\text { - Creating better quality drawings to facilitate communication with partners } \\
\text { - Greater flexibility and faster responses in the design modifications } \\
\text { - Offer data entry for computerized manufacturing }\end{array}$ \\
\hline EDI & $\begin{array}{l}\text { - Possibility of integration between organizations in applications like accounts } \\
\text { payable, inventory control, shipping and production planning. }\end{array}$ \\
\hline Fleet tracking & $\begin{array}{l}\text { - Contribute to the management of the fleet and cargo and to control the hours } \\
\text { of service of drivers }\end{array}$ \\
\hline MES & $-\quad$ Flexible manufacturing process and high quality. \\
\hline TMS & $\begin{array}{l}\text { - Reduction of costs. } \\
\text { - Efficient management and coordination of freight transportation efforts. }\end{array}$ \\
\hline WMS & $-\quad$ Improvement of the distribution process. \\
\hline CRM & $-\quad$ Satisfaction and Customer Loyalty \\
\hline RF & $\begin{array}{l}\text { Reduction of the costs of distribution warehouses, retail and handling } \\
\text { stockouts. }\end{array}$ \\
\hline SCP & $\begin{array}{l}\text { Obtaining the real data demand, time and inventory. } \\
\text { integrating and efficient flow of information in organization and / or between }\end{array}$ \\
\hline ERP & \begin{tabular}{l} 
and partners. \\
\hline
\end{tabular} \\
\hline
\end{tabular}

Other authors reported the following benefits of the integration of IT and SCM:

Sanders et al. [8] showed a direct relationship between the use of technology in SCM and it was reported that organizations use IT more than normal in your industry, to achieve more operational benefits such as reduced costs and cycle times.

Levary [9] suggests that the benefits include: 1 . Minimizing the bullwhip effect, 2 . Maximize the efficiency of conducting activities along the supply chain, 3 . Minimize inventory throughout the supply chain, 4 . Minimize cycle times along the supply chain, 5 . Achieve an acceptable level of quality throughout the supply chain.

Dias et al. [10] list the following benefits achieved by the use of IT in SCM: ( i ) sharing instant information, (ii ) sharing programs that increase operational efficiency, ( iii ) real-time monitoring of the consumer load; ( iv ) development of global sales channels (v) reduction of inventories, and ( vi) greater flexibility . 
These benefits can be obtained as the level of installation and use of IT systems, which directly affects the performance of the supply chain.

\section{Type of Research}

\section{Methodology}

To achieve the objective of this work was carried out a survey with consultants and professionals in IT and supply chain who work in large companies. To collect the data needed for analysis, we used the exploratory research of a qualitative nature.

For Gil [12], the exploratory research aims to provide greater familiarity with the problem in order to make it more explicit .

Zikmund [13] considers that exploratory studies are conducted to clarify ambiguous problems, research is needed to better understand the dimensions of the problems .

The qualitative approach presents a reality that can not be quantified or measured items and involves subjective reality research. You can work with the data without specific statistical treatment, seeking understanding of reality [14] .

The research can be categorized as "survey" as it involves the question directly to respondents, members of a significant sample of the research universe and whose behavior you want to know, because their results can lead to conclusions corresponding to the data collected [11].

\section{Sample and Actors Research}

The actors of the research are:

- IT Consultants

- Supply Chain Consultants.

- Employees of companies working with IT and Supply Chain.

Questionnaires were sent to 60 companies and 14 responded and, of these, most opted not to disclose the name or corporate fantasy for strategic reasons.

\section{Research Instrument}

For Gil [12] , most cases of exploratory research involves literature review and interviews.

The interview, at Gil [11], is a technique in which the researcher has investigated against him and asks questions, the objective of obtaining the data of interest to research.

The research instrument of this work consists of a questionnaire with closed and open questions. Some of the responses were directed by the interviewer, in the form of performance notes which aim to detect the degree of importance, according to the intensity of perception for that aspect.

\section{Analysis of results}

The survey showed that all IT systems reported by Patterson et.al. [3], are used by some of the companies surveyed. The systems that are most commonly used by companies are those that provide greater operational benefits, as Sanders et.al. [8], including:

1) Barcoding and ERP, shown in Figure 01, were the most used systems in 11 of the 14 companies surveyed (78.5\%). The companies surveyed confirmed the operational benefits that offer the use of the barcode as ease of use and elimination of paper in data collection and integration and efficiency in the flow of information in the organization and / or between it and its partners in the case of ERP [7]. 


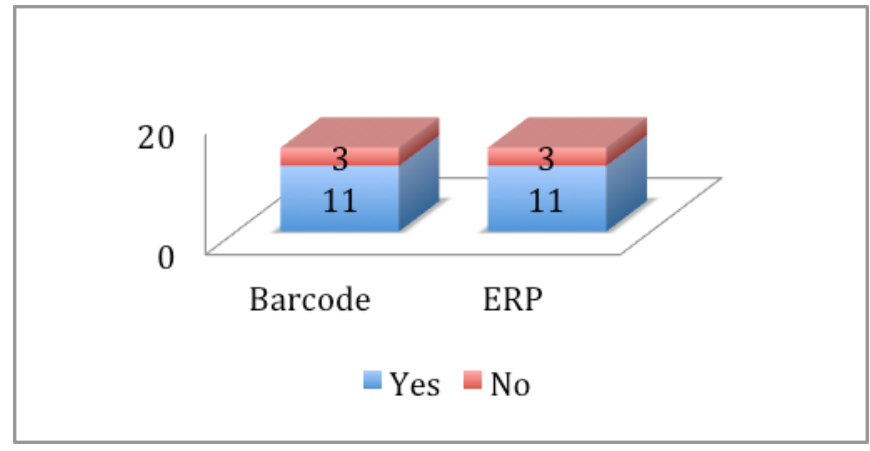

Figure 01 - Use of Barcode and ERP

2) Legacy systems, CAD, BI and WMS, had a use of 11 of the companies surveyed (71.4\%) as noted in Figure 02. Legacy systems provide operational benefits as accesses to data and legacy systems, but are still used by companies. The BI organizes and structures the transaction data of an organization, facilitates the analysis in order to benefit the operations and support their decisions. To Morais e Tavares [7], the benefits obtained with CAD are creating movements in design allows testing before production, reduced time for product development, design creation of better quality to facilitate communication with partners, greater flexibility and faster responses in the design modifications and offer input to the computerized manufacturing, whereas for the WMS, the benefit is the improvement of the distribution process.

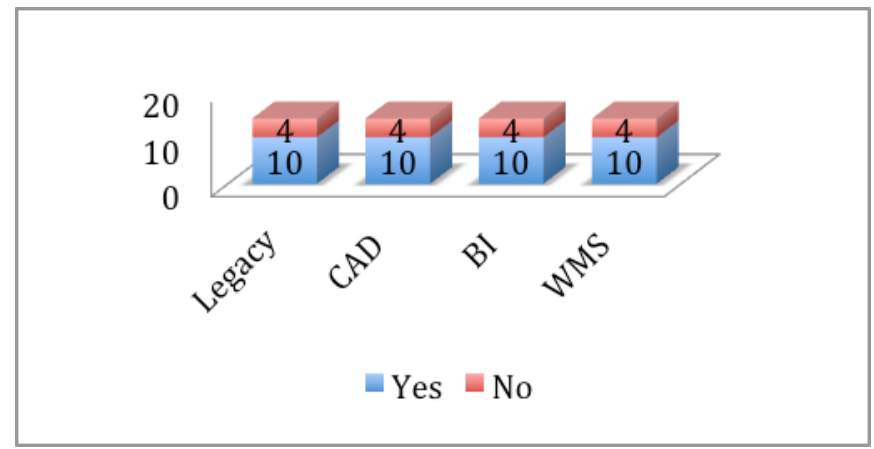

Figure 02 - Use of legacy systems, CAD, BI and WMS

3) The EDI and its use, as demonstrated in Figure 03, was reported by 9 of the 14 companies surveyed (64.2\%). The main benefit presented is the possibility of integration between organizations in applications like accounts payable, inventory control, shipping and production planning.

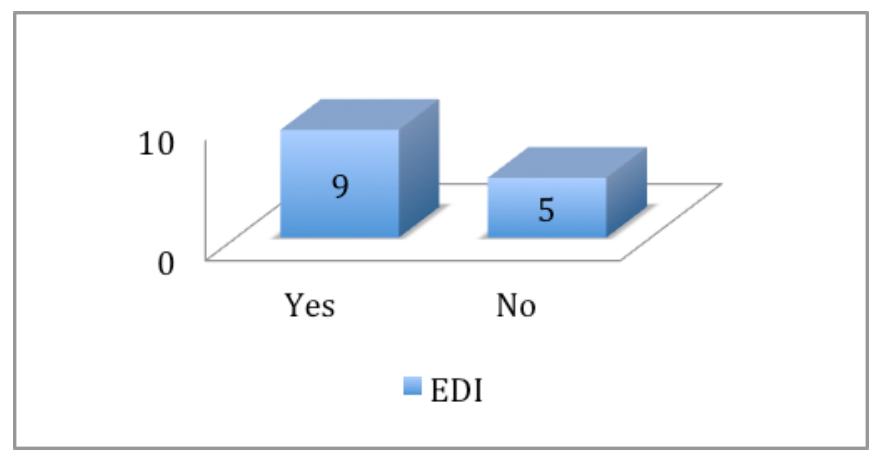

Figure 03 - Use of EDI

4) The use of CRM, DFS and SCP systems, as in Figure 04, are present in half of the companies surveyed (50\%). Halves of the companies answered "No", this may indicate that these companies have caution in using these systems, or are not convinced about the benefits that they can provide since some benefits are geared more for planning than for operating as satisfaction and 
loyalty through CRM, obtaining the real data demand, time and inventory by SCP and forecast demand for products and services obtained from the DFS, as shown Morais and Tavares [7].

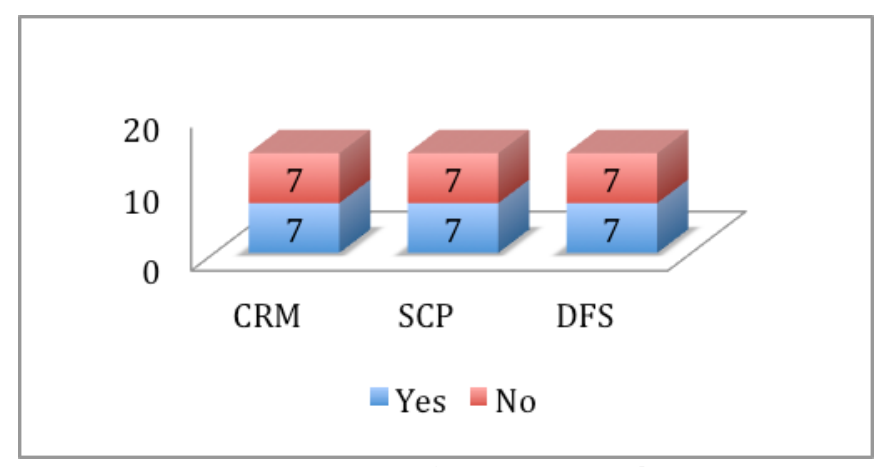

Figure 04 - Use of CRM, SCP and DFS

5) Among the seven fleet tracking systems, AQC, MES, TMS, WIS, PDM and RF, shown in Figure 05, five of the 14 companies surveyed - (35\%) - answered "Yes" Tracking fleet, AQC, MES, TMS, WIS and 6 companies (42\%) answered "Yes" to PDM and RF. Research has shown that the benefits offered by these systems as fleet management and cargo, flexible manufacturing process and high-quality, cost reduction and efficient management of freight, reducing expenses distribution warehouses, etc., relate to processes and management and not with the operational benefits, which does not make them attractive for use by all companies.

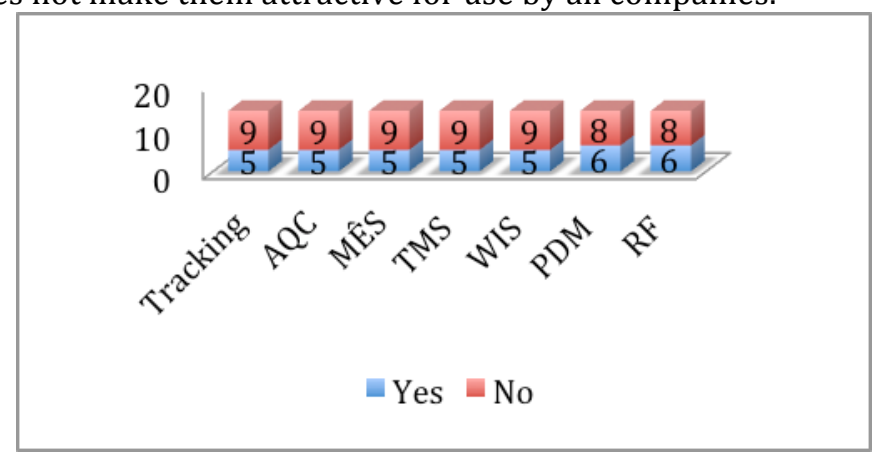

Figure 05 - Use of fleet tracking, AQC, MES, TMS. WIS, PDM and RF.

6) In both B2B and RFID systems, shown in Figure 06, we note that the systems were less used by 14 companies surveyed, 4 for B2B companies (28.5\%) and 3 companies for RFID (21.5\%). It can be deduced that the low utilization is on the point that the two systems need specific equipment for deployment and the benefits are not operational.

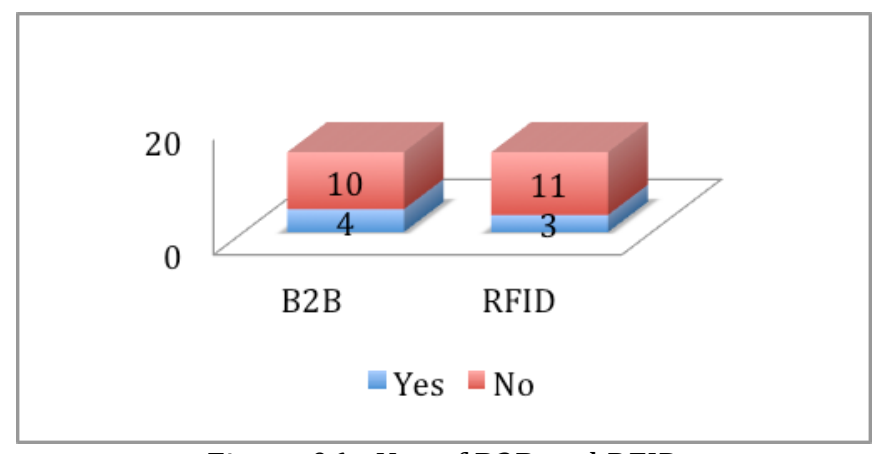

Figure 06 - Use of B2B and RFID

Questioned whether the respondents which would be applied to the IT systems of the future SCM. Two systems were cited VMI (Vendor Managed Inventory) - Stocks Managed by the Provider and ERP version 3. 


\section{Conclusions}

The research achieved the objectives of verifying the main IT systems used in the supply chain and what are the most commonly used by businesses.

All systems surveyed in the literature are used by respondents, and the most used are those that offer operational benefits such as ERP, barcode, legacy systems, CAD , BI and WMS .

New technologies also " scare " companies which leads to them not adopt these technologies more quickly when launched, as found in research with B2B and RFID.

It was noticed that the systems for planning and management of SCM, and their usage in enterprises are increasing.

Thus, we can conclude that the use of IT in the supply chain directly impacts in the areas of planning, manufacturing suppliers, customers and delivery.

As a future project, expected to use these items for review and creation of indicators in order to measure the level of impact in different areas of the company.

The matter does not end here, is a contribution to future discussions on the subject and quest for improvement of systems analysis of information technology in supply chain management .

\section{Acknowledgment}

$\mathrm{CNPq}$, for making it possible and funded this research.

\section{References}

[1] BANDEIRA, R. A. M.; MAÇADA, A. C. G. Information technology in supply chain management: the case of the industry of gases. Produção, v. 18, n. 2, p. 287-301, 2008 (In portuguese).

[2] MING-LANG T.; KUO-JUi W.; THI T. N. Information technology in supply chain management: a case study, Procedia - Social and Behavioral Sciences, v. 25, p.257-272, 2011.

[3] PRAJOGO, D. 1.; OLHAGER, J. Supply chain integration and performance: The effects of long-term relationships, information technology and sharing, and logistics integration. International Journal of Production Economics, v. 135, p.514-522, 2012.

[4] DAVENPORT, T. H.; BROOKS, J. D. Enterprise systems and the supply chain Journal of Enterprise Information Management Volume 17 . Number 1 . 2004

[5] PATTERSON, K.; GRIMM, C.; CORSI, T. Adopting new technologies for supply chain management. In: Transportation Research Part E, v. 39, p.95-121, 2003.

[6] IGUIDER, Y and MORITA, H. Toward Next Generation E-Marketplace for Small Business. International Journal of Computer Information Systems and Industrial Management Applications. Volume 5. p. 227-234. 2013

[7] MORAIS, K M N; TAVARES, E. Use of information technology in managing supply chain in São Luís do Maranhão and opportunities for the development of local suppliers. Interações (Campo Grande), Campo Grande, v. 12, n. 2, Dec. 2011 (In portuguese)

[8] SANDERS, N.R.; PREMUS, R. IT applications in supply chain organizations: a link between competitive priorities and organizational benefits. Journal of Business Logistics, v. 23, p.65-83. 2002.

[9] LEVARY, R. R., Better supply chains through information technology. Industrial Management v. 42 , n. 3, p. 24-30, 2000.

[10] DIAS, R.; PITASSI, C.; JOIA, L. Integrated management of the supply chain. Rio de Janeiro: FGV, EBAPE, 2003 (In Portuguese).

[11] GIL, A. C. Methods and Techniques of Social Research, São Paulo, Editora Atlas, 1997 (In portuguese).

[12] GIL, A. C. How to develop research projects. São Paulo. Editora Atlas, 2002 (In portuguese)

[13] ZIKMUND, W.G. "Business Research Methods". 6th edition. The Dryden Press. Fort Worth. 2000

[14] COSTA, M. A. F.; COSTA, M. F. B. Research Methodology - Concepts and Techniques, Rio de Janeiro, Ed. InterCiência, 2001 (In portuguese). 